\title{
Effects of Landscape Changes on Soil Erosion in the Built Environment: Application of Geospatial-Based RUSLE Technique
}

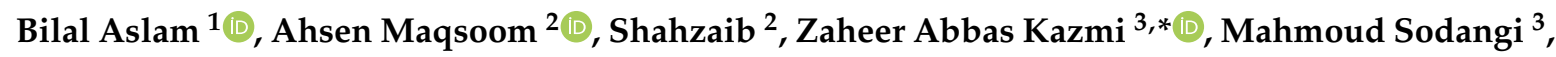 \\ Fahad Anwar ${ }^{3}\left({ }^{(0}\right.$, Muhammad Hassan Bakri ${ }^{3}$, Rana Faisal Tufail ${ }^{2}$ and Danish Farooq ${ }^{4}($ ) \\ 1 Department of Earth Sciences, Quaid-i-Azam University, Islamabad 45320, Pakistan; \\ bilalaslam45@gmail.com \\ 2 Department of Civil Engineering, COMSATS University Islamabad, Wah Campus 47040, Pakistan; \\ ahsen.maqsoom@ciitwah.edu.pk (A.M.); FA16-CVE-077@cuiwah.edu.pk (S.); \\ faisal.tufail@ciitwah.edu.pk (R.F.T.); \\ 3 Department of Civil \& Construction Engineering, Imam Abdulrahman Bin Faisal University, \\ Dammam 31441, Saudi Arabia; misodangi@iau.edu.sa (M.S.); faafarooqi@iau.edu.sa (F.A.); \\ mhbakri@iau.edu.sa (M.H.B.) \\ 4 Department of Transport Technology and Economics, Budapest University of Technology and Economics, \\ Stoczek u. 2, H-1111 Budapest, Hungary; farooq.danish@mail.bme.hu \\ * Correspondence: zakazmi@iau.edu.sa
}

Received: 24 June 2020; Accepted: 20 July 2020; Published: 22 July 2020

check for updates

\begin{abstract}
The world's ecosystem is severely affected by the increase in the rate of soil erosion and sediment transport in the built environment and agricultural lands. Land use land cover changes (LULCC) are considered as the most significant cause of sediment transport. This study aims to estimate the effect of LULCC on soil erosion potential in the past 20 years (2000-2020) by using Revised Universal Soil Loss Equation (RUSLE) model based on Geographic Information System (GIS). Different factors were analyzed to study the effect of each factor including $\mathrm{R}$ factor, $\mathrm{K}$ factor, LS factor, and land cover factor on the erosion process. Maps generated in the study show the changes in the severity of soil loss in the Chitral district of Pakistan. It was found out that $4 \%$ of the area was under very high erosion risk in the year 2000 which increased to $8 \%$ in the year 2020. An increase in agricultural land (4\%) was observed in the last 20 years which shows that human activities largely affected the study area. The outcomes of this study will help the stakeholders and regulatory decision makers to control deforestation and take other necessary actions to minimize the rate of soil erosion. Such an efficient planning will also be helpful to reduce the sedimentation in the reservoir of hydraulic dam(s) constructed on Chitral river, which drains through this watershed.
\end{abstract}

Keywords: sediment transport; soil erosion; RUSLE (Revised Universal Soil Loss Equation model); human activities

\section{Introduction}

World land resources are declining day by day due to soil erosion, so much that it has become the main focus of researchers and engineers [1]. Different studies have been carried out for the sustainability of natural habitat [2-5]. It is a loss of soil rich with nutrients that affects the productivity and sustainability of the original soil [6]. Approximately $80 \%$ of agricultural areas are facing higher rates of soil loss, and transported sediments severely affect the natural and built environment. Erosion of soil depletes the storage capacity of reservoirs and dams which ultimately decreases the power generation capacity. It also disturbs the agricultural output and aquatic life by polluting water in the rivers [7]. 
According to Chuenchum et al. [7], about 2.5 to 4 billion tons of soil is annually eroded worldwide. There are many influencing factors of soil erosion including slope, elevation, rainfall, plane curvature, drainage density, lithology, and lineaments. However, land use and climatic changes are the two most significant factors which affect the sediment transport to river tributaries. It is predicted that human actions will disturb the climate and land use land cover (LULC) significantly. Therefore, it is very important to evaluate the effect of these changes on soil erosion potential [8]. According to the past research, it has been observed that landscape characteristics are responsible for about $65 \%$ to $74 \%$ of changes in sediment yield and soil erosion. Changes in streamflow discharge due to land use also increase the intensity of soil erosion. Usually, it is observed that areas with more grassland are less vulnerable to soil erosion, whereas arable lands are more susceptible to soil loss [9].

Soil degradation is considered a serious issue due to human actions. Human beings have largely contributed to each influencing factor of land use [10]. It may be due to natural factors including different geomorphological and climatic conditions [11]. Variations in natural vegetation are observed as the first effect of this impact, irrespective of human contribution in the natural environment [12]. When LULC is changed to agricultural land from natural vegetation especially in mountainous regions, it fallouts with an increase in soil erosion rate due to crop production [13]. Land-use changes usually occur during agricultural development, which lead to the hydrological responses that further increases the rate of soil loss. Increased deforestation and growing agricultural and urban land in the tropical areas influence the intensity of soil erosion. It also plays an important role in the performance of hydraulic structures. An increased soil erosion and sedimentation fills the reservoirs of hydraulic dams, which ultimately decreases the power generation capacity.

Land use land cover change (LULCC) is the major influencing aspect that contributes to the increasing rate of soil erosion. It harms the environment by disturbing the supply of water, the capacity of storage basin, agricultural yield, and availability of freshwater in the area [8]. Land cover such as plantation directly affects soil erosion $[14,15]$. A generalized analysis of land use may be difficult if there is a lack of consistent time-series data for land use or land cover. Recently, scholars are interested in highlighting the effect of the environment on the erosion process. Their sole focus is on the effects of erosion including soil production and reducing the production of crops and affecting water quality by carrying nutrients, heavy metal impurities, and pesticides to surface water bodies. Sediment transport is also responsible for affecting channel, floodplain morphology, and sedimentation of reservoirs [16]. The above-mentioned impacts on soil erosion due to LULC changes can be minimized by estimating the loss of soil. For the estimation of average yearly soil loss, the RUSLE model is most commonly used by researchers, engineers, and planners. Due to its simplicity, ease of use and integration of different factors affecting soil erosion, RUSLE model is preferred over many other methods used for the estimation of soil loss $[17,18]$. It consists of six parameters including slope length factor (LS), erosion control practices factor $(\mathrm{P})$, soil erodibility factor $(\mathrm{K})$, cover management factor $(\mathrm{C})$, and rainfall erosivity factor $(\mathrm{R})$, which make it possible to calculate average yearly soil loss. The value of each factor is adapted for statistical and empirical data with the integration of GIS or is taken from the previous literature. The soil erosion can also be calculated by the integration of ArcGIS, MATLAB and SolidWorks software [19]. RUSLE in conjunction with GIS has become an effective tool for assessing soil erosion. Many researchers used the integration of RUSLE model with GIS in their study to estimate the rate of soil erosion [20-22]. Soil and water conservation practices (SWCPs) have a positive impact on soil properties. A relevant study has been conducted in Ethiopia [23].

A study was conducted by Sharma et al. [8] on the effect of LULC on erosion process in the reservoir from 1989-2004. This study illustrated that a slight increase in mean soil loss was observed. In 1989, it was $12.11 \mathrm{t} / \mathrm{ha} / \mathrm{y}$ and in 2004 it became $13.2 \mathrm{t} / \mathrm{ha} / \mathrm{y}$. Results indicated that deforestation and increased wasteland in higher slopes increased the mean soil loss rate in 15 years. Another research in the Western Polish Carpathians shows that due to the increase in plantation and a decrease in the rate of cultivation, the rate of eroded soil decreased in the last 160 years (1846-2009). The rate of soil erosion in the year of 1846 was 18.13 tons/ha/y and it decreased to 4 tons/ha/y in the year 2009 [14]. 
Ouyang et al. [9] demonstrated the behavior of land-use changes, which shows that it has a more severe effect on erosion rate than changes in the properties of soil. For the estimation of soil loss in the Kelantan River basin, Abdulkareem et al. [24] used the USLE (universal soil loss equation) model based on GIS. Arable areas have a greater susceptibility to erosion process; research [25] illustrated that arable lands are approximately ten times more vulnerable to soil loss than orchards. In recent years, many studies have been conducted to analyze the impact of LULCC on soil erosion and sediment transport rate $[14,15,20,26,27]$.

Soil loss is estimated by the nature of erosion process and data availability of the factors that contribute towards erosion. In the past, soil erosion estimation was done by using different methods ranging from factor-based approaches to process-based models. Now, RUSLE model is the most widely used considering its simplicity, and its input parameters are easily available. Investigation of impact of LULCC on soil erosion can be done by analyzing the effect of land use land cover changes (LULCC) on soil erosion potential and discharge of sediments through historic satellite images [8]. In this study, the main purpose is to figure out the potential of soil loss in the mountainous region, which changes due to an increase in agriculture production and decrease in the forest cover. For this purpose, a GIS-based RUSLE model is used to estimate the long-term effect of LULC on soil erosion. The results of the study are demonstrated in the form of temporal severity maps, highlighting the areas with high land use changes and their impact on soil erosion intensity. The quantitative estimation of soil loss due to LULCC is important for researchers and planners to take necessary actions to minimize the rate of soil erosion. Such an efficient planning will also be helpful to reduce the sedimentation in the reservoir of hydraulic dam(s) constructed on Chitral river, which drains through this watershed.

\section{Methodology}

\subsection{Study Area}

The northernmost part of Pakistan is the Chitral district which is situated in the world's largest mountains (Figure 1). Its coordinates are $35^{\circ} 53^{\prime} 15^{\prime \prime} \mathrm{N}$ and $71^{\circ} 48^{\prime} 01^{\prime \prime} \mathrm{E}$. Its neighbors include Afghanistan, China, Central Asian States, and Northern Areas of Gilgit. Chitral district is $322 \mathrm{~km}$ away from the provincial capital of Khyber Pakhtunkhwa. The DEM (digital elevation model) (Figure 2) clearly shows that the study area has rugged mountainous terrain with variation in altitude from $1053 \mathrm{~m}$ to $7695 \mathrm{~m}$. In the north-east, it is bounded by the Karakoram, in the south by Hindu Raj Range and north-west by Hindu Kush mountains. Moreover, there are 40 peaks within an area of $14,850 \mathrm{~km}$ and altitude ranges from $1094 \mathrm{~m}$ at Arandu to $7726 \mathrm{~m}$ at Tirchmir. The Chitral district is composed of several valleys. The Chitral Mastuj valley is the largest and most important valley, expanding from the Afghan border to Arandu on the southern tip. Other important valleys include Terich, Shishi, Owir, Mulkhow, Lotkoh, Laspur, Torkhow, and Ashrat. The main Chitral valley is $354 \mathrm{~km}$ long and its width varies from $180 \mathrm{~m}$ to $4800 \mathrm{~m}$. The whole study area is drained into Chitral river through several tributary channels. From the origin of the glacier Chianter, the river enters Afghanistan at Arandu. The study area is a mountainous tract that receives about $10-25 \mathrm{~mm}$ rain per month. The minimum and maximum temperature remain between $21^{\circ} \mathrm{C}$ and $37^{\circ} \mathrm{C}$, respectively. Since high mountains prevent much of the monsoonal wind and moisture from reaching the study area, the summer season usually receives less amount of precipitation. Therefore, the region is not considered favorable for vegetation growth. On 16 July 1973, a maximum discharge of $1586 \mathrm{~m}^{3} / \mathrm{s}$ was recorded while March 10, 1964 witnessed a minimum value of $46 \mathrm{~m}^{3} / \mathrm{s}$. The river flows undeviatingly the whole year because of the melting of glaciers and snow. During the season of monsoon, i.e., July-September, some extra runoff can be recorded. The river siphons a wide area of a steep slope and widespread area covered with snow, which contributes half of the discharge to the Kabul River. For irrigation and hydropower generation, a dam was constructed on the Chitral River having a maximum output of 250,000 kW. The location of the dam is about $30 \mathrm{~km}$ west of Peshawar. Due to the extensive silting, the reservoir is almost 
full. Throughout summers and winters, the power generation capacity of the dam has dropped to $64,000-20,000 \mathrm{~kW}$, correspondingly.

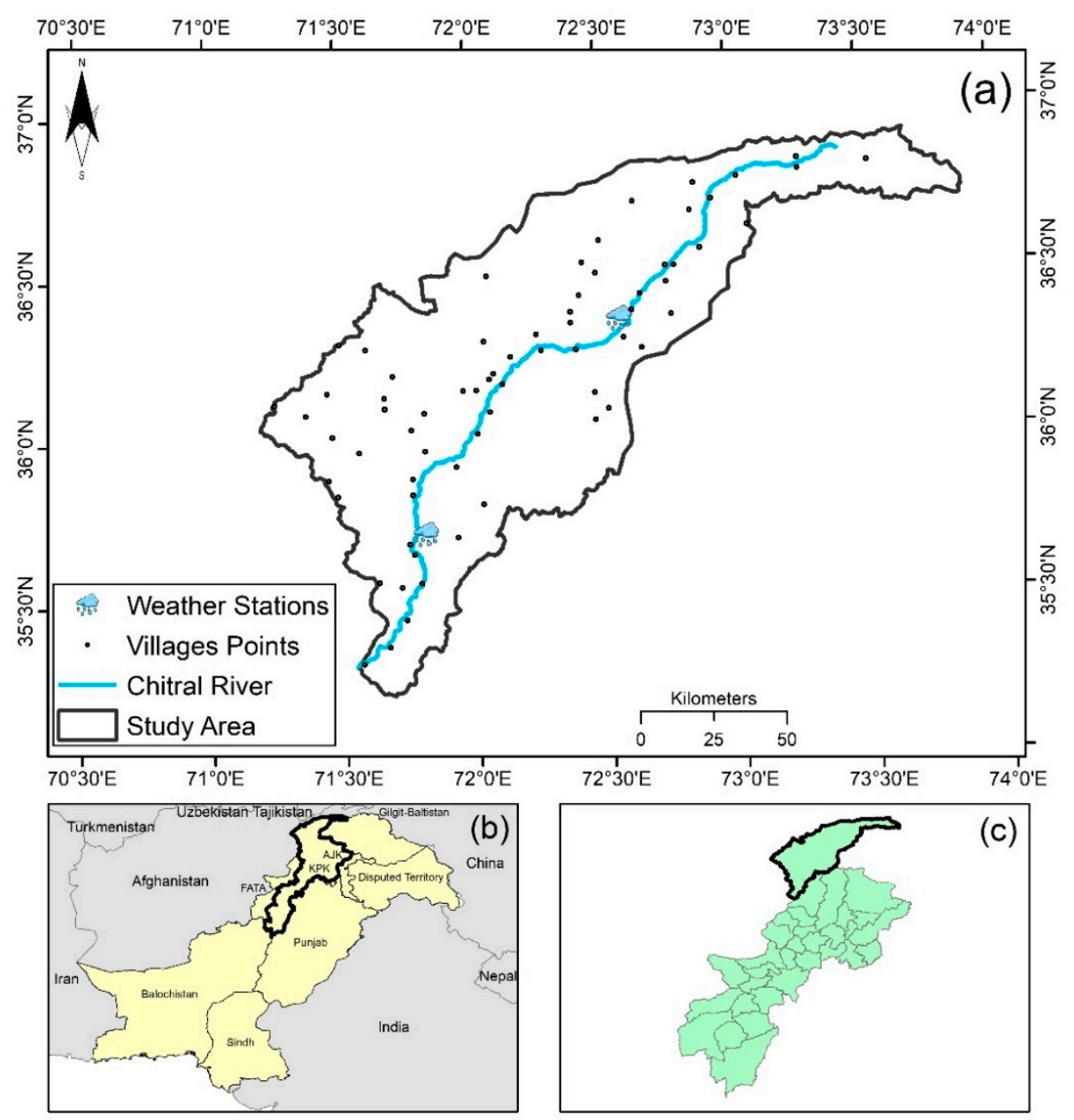

Figure 1. (a) Study area (Chitral District) with locations of weather stations and villages; (b) KPK Province of Pakistan in which the study area lies; (c) Location of study area in KPK Province.

\section{2. $L U L C$}

For the assessment of LULC, Landsat satellite data were obtained. Landsat is the largest program run by NASA/USGS for earth's imagery. Landsat 7 was used to develop the land cover maps of 2000 and 2010 while Landsat 8 was used for 2020. All three land covers were developed from satellite imageries having zero cloud cover, taken during the period of least snow cover in the area. Along with this data, practical samples were also collected from the field (study area). Based on Landsat satellite data and samples, supervised classification for the years 2000, 2010, and 2020 is made. Accuracy assessment is based on the following two parameters.

\subsection{Precipitation}

Precipitation data is required for the calculation of rain erosivity factor (R). This factor justifies the extent and intensity of every single rainfall throughout a year. This study utilized Satellite Rainfall Data of GPM (Global Precipitation Measurement). This satellite data is the product of NASA (National Aeronautics and Space Administration). It is widely used because of its enhanced accuracy. The annual rainfall data for the two meteorological stations situated in the study area (mentioned in Figure 1) was obtained from the Pakistan Meteorological Department. It was integrated with the satellite data to validate the results. 


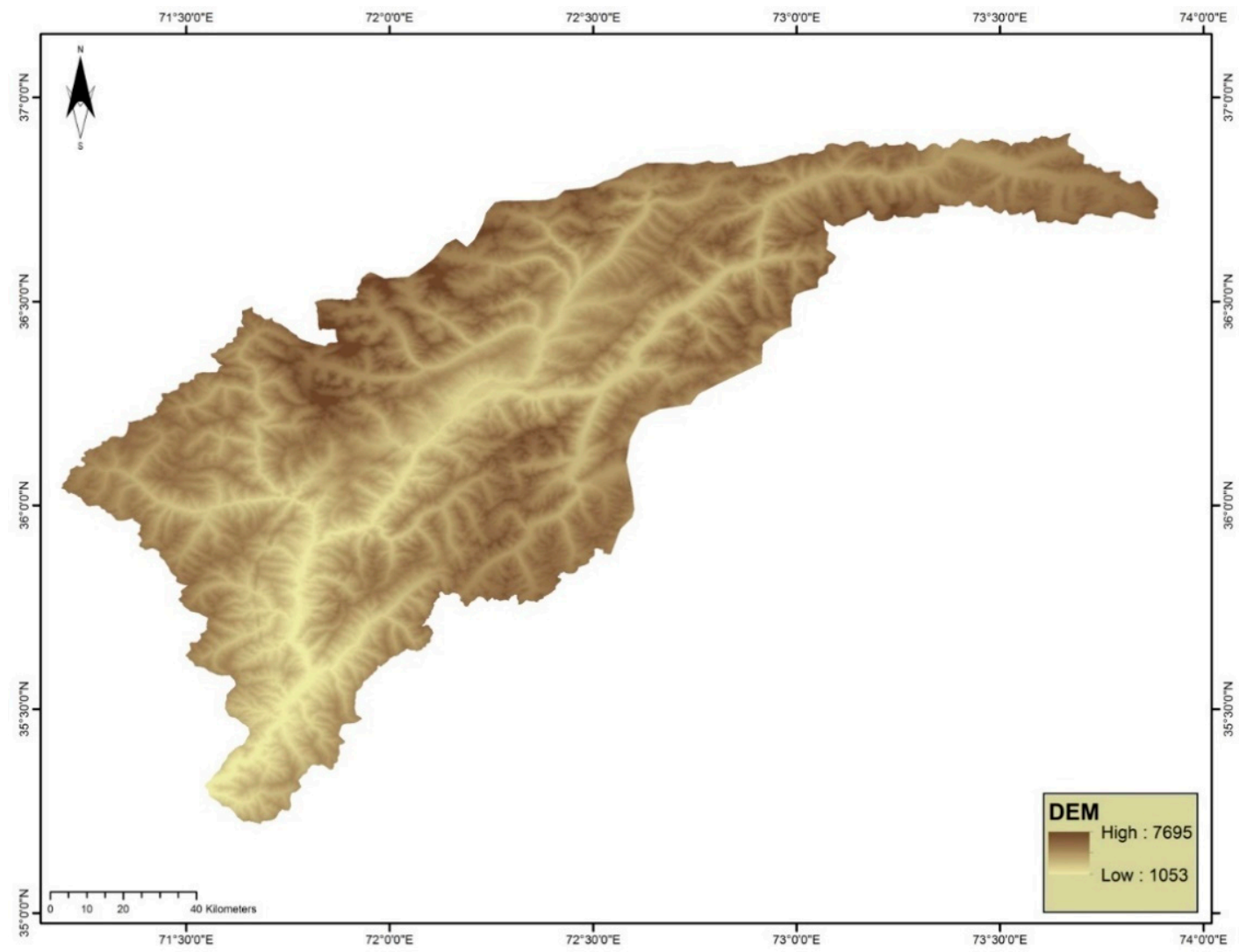

Figure 2. Digital Elevation Model (DEM) of the study area.

\subsection{RUSLE Model}

The soil loss due to water is most commonly estimated by using the RUSLE model because it is simple, with easy availability of input data, and wide-ranging of its applicability. In this study, RUSLE model is used in combination with GIS to calculate the LULCC. Modeling of soil erosion is an important part of current techniques used in the study of geomorphology along with other practices like photointerpretation, rainfall simulation, and GIS [28,29]. This is described by the following equation,

$$
E=\text { R.K.LS.C.P }
$$

where $E$ is the amount of average annual soil loss (tons/ha/y), $R$ is rainfall erosivity factor (MJ mm/ha/h/y), $K$ is soil erodibility factor (tons/ha)/(MJ mm/ha/h), LS is a topographic factor (dimensionless), $C$ is vegetation cover and management factor (dimensionless), and $P$ is soil and water conservation factor (dimensionless).

Rainfall erosivity factor is the most important constraint of the erosion process [30]. Analytical calculation of the $\mathrm{R}$ factor is impossible because detailed long-term precipitation data is not available. So, $\mathrm{R}$ factor is estimated with the help of other methods by using rainfall data available for it [31]. Modified Fournier Index (MFI), the most commonly used empirical method, was used in this research

$$
M F I=\sum_{j=1}^{12} \frac{p_{i}^{2}}{P}
$$

where, $p_{i}$ is monthly $\mathrm{i}$-month precipitation $(\mathrm{mm})$ and $P$ is yearly precipitation $(\mathrm{mm})$. 
Modified Fournier index and an R factor of RUSLE model are strongly linearly correlated [20]. Licznar [32] determined the correlation between the R factor of RUSLE and MFI for Poland and the power-law equation is defined as

$$
R=0.2265 \cdot M F I^{1.2876}
$$

This equation has been verified, validated [8] and applied in many studies targeting different parts of Pakistan $[4,33,34]$. Therefore, it can be assumed that this equation will provide accurate results for the area selected in this study.

There is a minor change in monthly and annual rainfall of two different periods, so they have the same R factor. The R factors of both from equation 3 and erosivity index are compared. Latocha et al. [28] in the Polish Mountains and Sudety and Drzewiecki et al. [35] in Polish Carpathians calculated the quantity of soil loss by using RUSLE model. The factor $\mathrm{K}$ denotes the erodibility of soil associated with vulnerability to runoff rate and soil loss. The following equation is used to find $\mathrm{K}$ factor,

$$
K=2.77 \cdot 10^{-6} \cdot M^{1.14} \cdot(12-O M)+0.043 \cdot(S-2)+0.033(P-3)
$$

where $\mathrm{M}$ is particle size parameter $(0.002-0.1 \mathrm{~mm}$ and $0.002-2.0 \mathrm{~mm}$ particle size), OM is organic matter percentage content, $\mathrm{S}$ is class of soil structure and $\mathrm{P}$ is class of soil permeability. Validation of Equation (4) was not possible due to the unavailability of data. Therefore, soil texture map of the area was used and the values were assigned according to $[8,33,36]$.

LS is the long slope which shows the surface topography. In this study, the equation proposed by Mitasova et al. [37] is used to find out the LS factor. Mancino et al. [38,39] have already used this equation in their research. DEM is used for calculation of flow accumulation and steepness of the slope.

$$
L S=(M+1)(A s \mid 22.13)^{m}(\sin \beta \mid 0.0896)^{n}
$$

where As is an area of un-slope drainage per width of contour, $\beta$ is slope gradient (radians), $m(0.4-0.6)$, and $n(1.0-1.4)$ are exponential factors and they depend on the type of dominant erosion. ArcMap GIS software 10.2 is used to calculate the LS factor.

$$
L S=P O W E R([\text { flow accumulation }] . \text { cell size } \mid 22.13,0.6) . P O W E R(\sin ([\text { slope }] .0 .01745) \mid 0.0896,1.3)
$$

$C$ represents the vegetation cover and management factor and it is used for the determination of the effect of management actions on soil erosion intensity. The NDVI indices have been used for the extraction of vegetative area, NDWI indices for water body extraction and NDBI for the built-up area. Accuracy of maps was validated from grouped samples. The erosion control practice factor $(\mathrm{P})$ is generally calculated for areas with erosion control practices. Since no such practices were in place in the study area, a constant raster value is used for soil and water conservation factor P [31,40]. This value ranges from 0 to 1 .

\section{Results}

\subsection{Dynamics of Land Use Land Cover}

General classification accuracy of 79\%, 81\% and 84\% for the LULC maps of 2000, 2010 and 2020 respectively were obtained by using different image processing techniques in collaboration with hybrid classification techniques (Table 1). The kappa coefficient of accuracy also improved throughout these years. The results of the year 2020 are more accurate as compared to the previous years. The classes of agriculture in the valley and water bodies have the highest accuracy.

The study area is classified into eight categories, that is, agriculture in sloping valley, agriculture in the valley, bare areas, natural herbaceous shrubs, natural high shrubs, natural trees, snow and ice, and water bodies. The study area is 1,449,120.7 ha and LULC was estimated for years of 2000, 2010, and 2020. Figure 3 clearly shows that the studied watershed is largely covered by natural 
herbaceous shrubs. The highly thick natural herbaceous shrubs and snow and ice are the two most plentiful land-use types, while a small percentage of the entire watershed is covered by bare areas, natural high shrubs, and natural trees. A very small area was occupied by agriculture in sloping valley, agriculture in valley and water bodies. Satellite examination helped in deriving the thematic maps of the last two decades (20 years). The composition or total extent of the individual LULC category/class is listed in Table 2.

Table 1. Accuracy of land use classes.

\begin{tabular}{|c|c|c|c|c|c|c|}
\hline \multirow{2}{*}{ Land Use Classes } & \multicolumn{2}{|r|}{2020} & \multicolumn{2}{|r|}{2010} & \multicolumn{2}{|r|}{2000} \\
\hline & $\begin{array}{l}\text { Class } \\
\text { Accuracy } \\
(\%)\end{array}$ & $\begin{array}{l}\text { Overall Accuracy } \\
\text { (\%) and Kappa } \\
\text { Coefficient }\end{array}$ & $\begin{array}{c}\text { Class } \\
\text { Accuracy } \\
(\%)\end{array}$ & $\begin{array}{l}\text { Overall Accuracy } \\
\text { (\%) and Kappa } \\
\text { Coefficient }\end{array}$ & $\begin{array}{l}\text { Class } \\
\text { Accuracy } \\
(\%)\end{array}$ & $\begin{array}{c}\text { Overall Accuracy } \\
\text { (\%) and Kappa } \\
\text { Coefficient }\end{array}$ \\
\hline Agriculture in Valley & 88 & \multirow{8}{*}{$84 \%$ and 0.82} & 86 & \multirow{8}{*}{$81 \%$ and 0.8} & 85 & \multirow{8}{*}{$79 \%$ and 0.77} \\
\hline $\begin{array}{l}\text { Agriculture in } \\
\text { Sloping Valley }\end{array}$ & 78 & & 76 & & 76 & \\
\hline Bare Areas & 89 & & 87 & & 84 & \\
\hline $\begin{array}{c}\text { Natural Herbaceous } \\
\text { Shrubs }\end{array}$ & 82 & & 80 & & 79 & \\
\hline Natural High Shrubs & 80 & & 78 & & 79 & \\
\hline Snow and Ice & 82 & & 77 & & 73 & \\
\hline Natural Trees & 79 & & 78 & & 77 & \\
\hline Water Bodies & 91 & & 87 & & 84 & \\
\hline
\end{tabular}
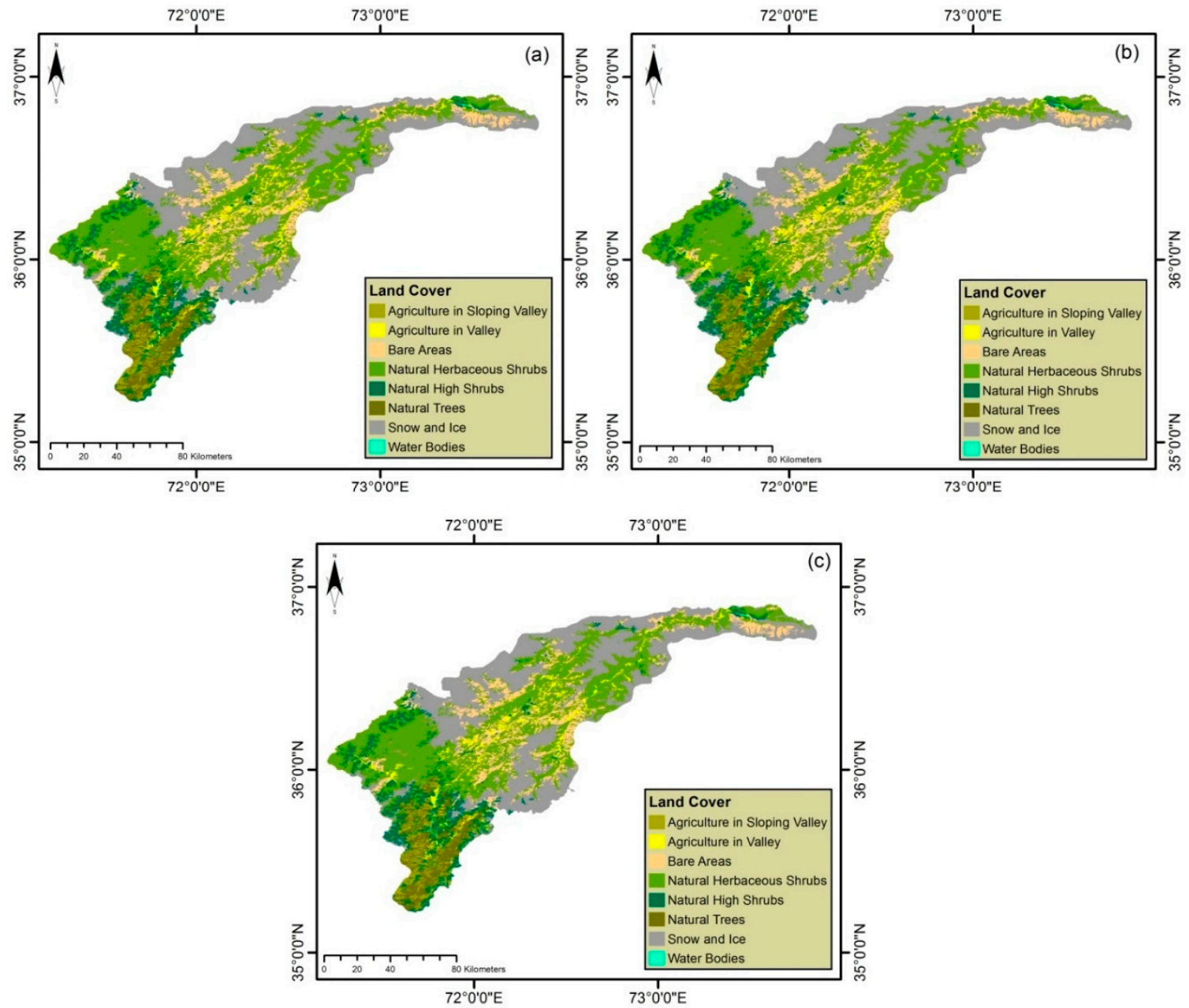

Figure 3. LULC (land use land cover) map of study area (a) 2020, (b) 2010, (c) 2000. 
Table 2. Land use land cover changes from 2000 to 2020.

\begin{tabular}{ccccccc}
\hline \multirow{2}{*}{ Land Use Classes } & \multicolumn{2}{c}{2020} & \multicolumn{2}{c}{$\mathbf{2 0 1 0}$} & \multicolumn{2}{c}{$\mathbf{2 0 0 0}$} \\
\cline { 2 - 7 } & Area (Ha) & Area (\%) & Area (Ha) & Area (\%) & Area (Ha) & Area (\%) \\
\hline Agriculture in Valley & $39,234.5$ & $3 \%$ & $28,982.4$ & $2 \%$ & $14,491.2$ & $1 \%$ \\
Agriculture in Sloping Valley & $51,107.9$ & $4 \%$ & $14,491.2$ & $1 \%$ & $14,491.2$ & $1 \%$ \\
Bare Areas & $161,053.9$ & $11 \%$ & $130,420.9$ & $9 \%$ & $115,929.7$ & $8 \%$ \\
Natural Herbaceous Shrubs & $515,637.5$ & $36 \%$ & $550,665.9$ & $38 \%$ & $565,157.2$ & $39 \%$ \\
Natural High Shrubs & $135,184.6$ & $9 \%$ & $86,947.2$ & $6 \%$ & $72,456.1$ & $5 \%$ \\
Snow and Ice & $465,076.1$ & $32 \%$ & $507,192.2$ & $35 \%$ & $521,683.6$ & $36 \%$ \\
Natural Trees & $80,471.7$ & $5 \%$ & $101,438.4$ & $7 \%$ & $115,929.7$ & $8 \%$ \\
Water Bodies & 1354.4 & $1 \%$ & $28,982.4$ & $2 \%$ & $28,982.4$ & $2 \%$ \\
Total & $1,449,120.7$ & $100 \%$ & $1,449,120.7$ & $100 \%$ & $1,449,121$ & $100 \%$ \\
\hline
\end{tabular}

It is obvious from Table 2 and Figure 4 that natural herbaceous shrubs and snow and ice remained the two most dominant land use classes throughout the study period. Together, these two classes occupy $75 \%$ of the area. Table 3 shows the changes in soil erosion of every individual class for all the studied years.

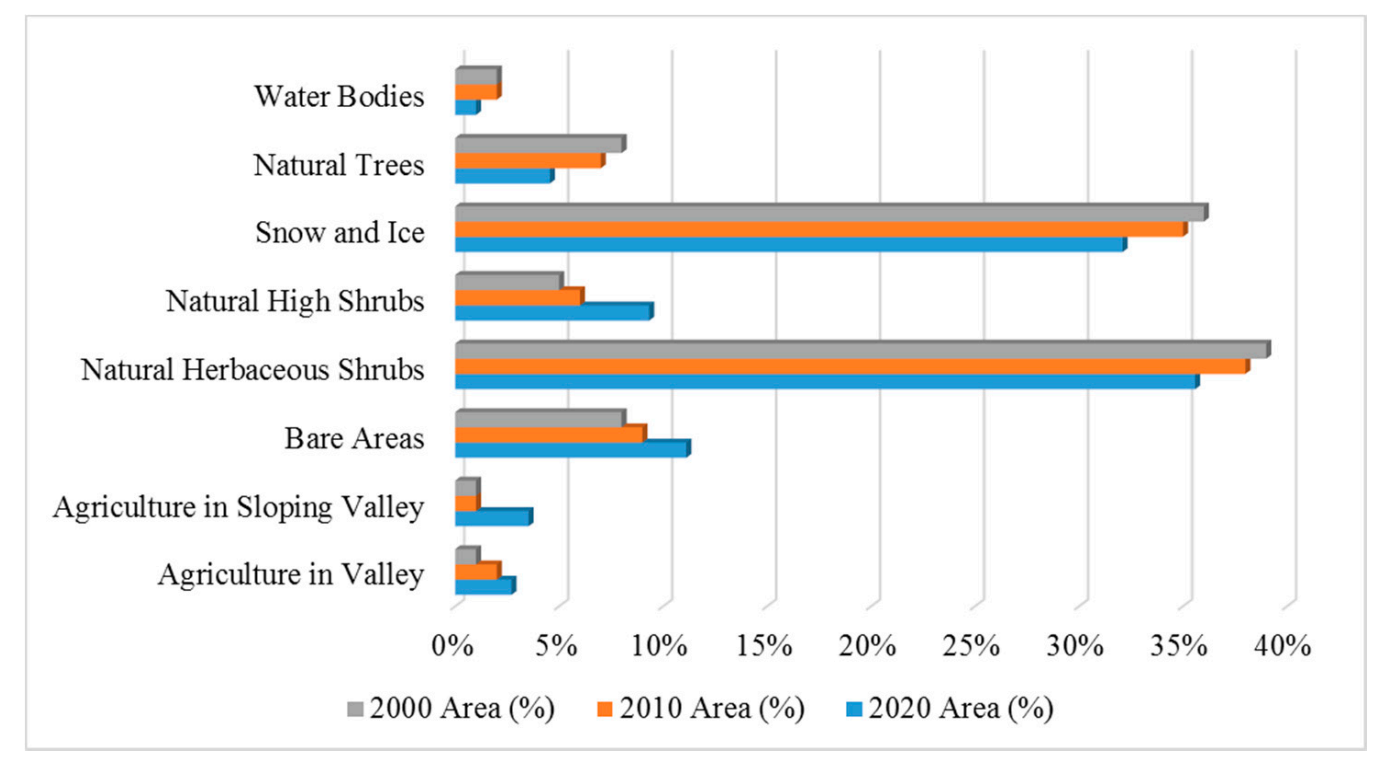

Figure 4. The trend of LULC from 2000 to 2020.

Table 3. Statistical analysis of land use classes.

\begin{tabular}{cccccc}
\hline \multirow{2}{*}{ Land Use Classes } & \multirow{2}{*}{ Soil Erosion Year } & \multicolumn{3}{c}{ Statistics (All Units in tons/ha/year) } \\
\cline { 3 - 6 } & & Mean & Min & Max & STD \\
\hline \multirow{2}{*}{ Agriculture in Valley } & 2020 & 144.09 & 5.97 & 1578.242 & 203.87 \\
& 2010 & 122.66 & 4.21 & 1464.702 & 173.43 \\
Agriculture in Sloping Valley & 2000 & 111.14 & 3.57 & 1370.052 & 143.54 \\
\hline \multirow{2}{*}{ Bare Areas } & 2020 & 198.9 & 6.45 & 5681.93 & 562.02 \\
& 2010 & 155.25 & 4.91 & 5242.39 & 513.59 \\
& 2000 & 123.57 & 4.48 & 4865.9 & 468.21 \\
\hline & 2020 & 177.04 & 5.03 & 5467.25 & 461.49 \\
& 2010 & 164.5 & 4.57 & 4963.82 & 414.54 \\
& 2000 & 152.15 & 4.12 & 4531.28 & 398.43 \\
\hline
\end{tabular}


Table 3. Cont.

\begin{tabular}{cccccc}
\hline \multirow{2}{*}{ Land Use Classes } & \multirow{2}{*}{ Soil Erosion Year } & \multicolumn{3}{c}{ Statistics (All Units in tons/ha/year) } \\
\cline { 3 - 6 } & & Mean & Min & Max & STD \\
\hline \multirow{3}{*}{ Natural Herbaceous Shrubs } & 2020 & 593.53 & 5.44 & $158,647.45$ & 7067.94 \\
& 2010 & 605.96 & 5.87 & $159,302.21$ & 6746.44 \\
& 2000 & 611.4 & 6.12 & $159,623.75$ & 6783.98 \\
\hline \multirow{2}{*}{ Natural High Shrubs } & 2020 & 116.32 & 5.64 & 8421.65 & 403.38 \\
& 2010 & 104.89 & 4.32 & 7988.97 & 367.45 \\
& 2000 & 103.57 & 4.22 & 7701.54 & 313.54 \\
\hline \multirow{2}{*}{ Snow and Ice } & 2020 & 1276.08 & 5.4 & $335,719.74$ & $15,947.62$ \\
& 2010 & 1152.43 & 4.99 & $334,365.09$ & $15,562.19$ \\
Natural Trees & 2000 & 1033.03 & 4.53 & $333,126.55$ & $14,907.43$ \\
\hline \multirow{2}{*}{ Water Bodies } & 2020 & 124.84 & 6.173 & 4767.86 & 286.48 \\
& 2010 & 115.44 & 5.54 & 4511.21 & 234.65 \\
& 2000 & 112.01 & 5.12 & 4186.56 & 212.47 \\
\hline
\end{tabular}

The area occupied by natural herbaceous shrubs is reduced to $515,637.5$ ha (36\%) in 2020 as compared to $550,665.9$ ha $(38 \%)$ in 2010 and $565,157.2$ ha (39\%) in 2000. This reduction is approximately $8.76 \%$ in comparison to the original area in 2000 . The snow and ice is the second major LULC class during the period of study. It also shows decrement. The area covered by snow and ice is reduced to $465,076.1$ ha (32\%) in 2020 as compared to 507,192.2 ha (35\%) in 2010 and 521,683.6 ha (36\%) in 2000.

There is a gain in the bare area during the study period. Content of minerals and organic matter in soil is suitable for soil quality because it affects the soil functioning positively [8]. The bare areas are mostly rich in organic matter and mineral content as compared to the agricultural land. This gain in the area is $28 \%$ in 2020 as compared to the total bare area in 2000. Natural high shrubs increased to $135,184.5$ ha $(9 \%)$ as compared to $86,947.2$ ha $(6 \%)$ in 2010 and $72,456.1$ ha $(5 \%)$ in 2000 . It shows an increment of $33.33 \%$ as compared to the original area in 2000. Water bodies of this region are reduced in these last 20 years. The water bodies decreased to 1354.4 ha (1\%) in 2020 as compared to $28,982.4$ ha $(2 \%)$ in 2010 and 2000. Natural trees of the study area also showed a decrement of $30.5 \%$ as compared to the original area in 2000 . These natural trees decreased to $80,471.7$ ha (5\%) in 2020 as compared to $101,438.4$ ha $(7 \%)$ in 2010 and $115,929.7$ ha $(8 \%)$ in 2000.

In contrast to all these land use classes, agriculture shows an increment in both valley and sloping valley. Agriculture in the valley increased to $39,234.5$ ha (3\%) in 2020 as compared to $29,892.4$ ha (2\%) in 2010 and 14,491.2 ha (1\%) in 2000. The increase in agriculture in the valley is gradual. The increase in agriculture in the sloping valley is not gradual. In the first decade, there was no change in agriculture in the sloping valley, but it rapidly increased in the second decade. It increased to 51,107.9 ha (4\%) in 2020 as compared to 1491.2 ha (1\%) in 2010 and 2000. Table 4 and Figure 5 show the land use class-wise soil erosion of every individual class in detail. It provides the ease to see and understand the changes throughout the study period because of its sub-divisions.

\subsection{Estimation of Sediment Yield and Soil Erosion}

The mean soil erosion of the entire watershed was 9.21 tons/ha/y in 2000, 12.43 tons/ha/y in 2010, and 15.63 tons/ha/y in 2020. Figures 6 and 7 show the spatial variation and distribution of different RUSLE factors and also the resultant map of soil erosion for all three years. The Warsak Dam which is the reservoir part of the watershed does not contribute to the net soil erosion, but it behaves as a sink for eroded particles of soil which was excluded from further analysis of soil erosion. The range of $\mathrm{R}$ factor was found to be $349.769 \mathrm{MJ} \mathrm{mm} \mathrm{ha}{ }^{-1} \mathrm{~h}^{-1} \mathrm{year}^{-1}$ as highest and 197.347 MJ mm ha-1 $\mathrm{h}^{-1}$ 
year $^{-1}$ as the lowest value, and variation in its spatial view is shown in the Figure $6 \mathrm{a}$. The range of $\mathrm{K}$ factor value lies between 0.1 and 0.4. The spatial distribution of the $\mathrm{K}$ factor is shown in Figure $6 \mathrm{~b}$. The calculated values of the LS factor using SRTM ranges from a minimum value of 0.2 for flat terrain to a maximum value of 6.3 for high-elevation areas, predominantly for hill slope region. The spatial distribution of the LS factor is shown in Figure 6c.

Table 4. Land use class-wise soil erosion severity.

\begin{tabular}{|c|c|c|c|c|c|c|}
\hline \multirow{2}{*}{ Land Use Classes } & \multirow{2}{*}{ Soil Erosion Year } & \multicolumn{5}{|c|}{ Soil Loss Class (\%) } \\
\hline & & Very Low & Low & Moderate & High & Very High \\
\hline \multirow{3}{*}{ Agriculture in Valley } & 2020 & 41 & 16 & 17 & 19 & 7 \\
\hline & 2010 & 38 & 23 & 29 & 6 & 4 \\
\hline & 2000 & 32 & 26 & 31 & 7 & 4 \\
\hline \multirow{3}{*}{ Agriculture in Sloping Valley } & 2020 & 51 & 21 & 17 & 9 & 2 \\
\hline & 2010 & 47 & 20 & 20 & 11 & 2 \\
\hline & 2000 & 41 & 19 & 24 & 13 & 3 \\
\hline \multirow{3}{*}{ Bare Areas } & 2020 & 7 & 18 & 26 & 35 & 14 \\
\hline & 2010 & 18 & 22 & 24 & 27 & 9 \\
\hline & 2000 & 21 & 23 & 26 & 23 & 7 \\
\hline \multirow{3}{*}{ Natural Herbaceous Shrubs } & 2020 & 39 & 18 & 21 & 11 & 11 \\
\hline & 2010 & 41 & 23 & 30 & 4 & 2 \\
\hline & 2000 & 40 & 31 & 20 & 5 & 4 \\
\hline \multirow{3}{*}{ Natural High Shrubs } & 2020 & 50 & 22 & 17 & 9 & 2 \\
\hline & 2010 & 53 & 20 & 15 & 10 & 2 \\
\hline & 2000 & 51 & 19 & 17 & 10 & 3 \\
\hline \multirow{3}{*}{ Snow and Ice } & 2020 & 61 & 26 & 7 & 5 & 1 \\
\hline & 2010 & 57 & 21 & 12 & 6 & 4 \\
\hline & 2000 & 60 & 25 & 8 & 5 & 2 \\
\hline \multirow{3}{*}{ Natural Trees } & 2020 & 39 & 18 & 21 & 11 & 11 \\
\hline & 2010 & 41 & 23 & 30 & 4 & 2 \\
\hline & 2000 & 40 & 31 & 20 & 5 & 4 \\
\hline \multirow{3}{*}{ Water Bodies } & 2020 & 61 & 26 & 7 & 5 & 1 \\
\hline & 2010 & 57 & 31 & 7 & 4 & 1 \\
\hline & 2000 & 60 & 25 & 8 & 5 & 2 \\
\hline
\end{tabular}

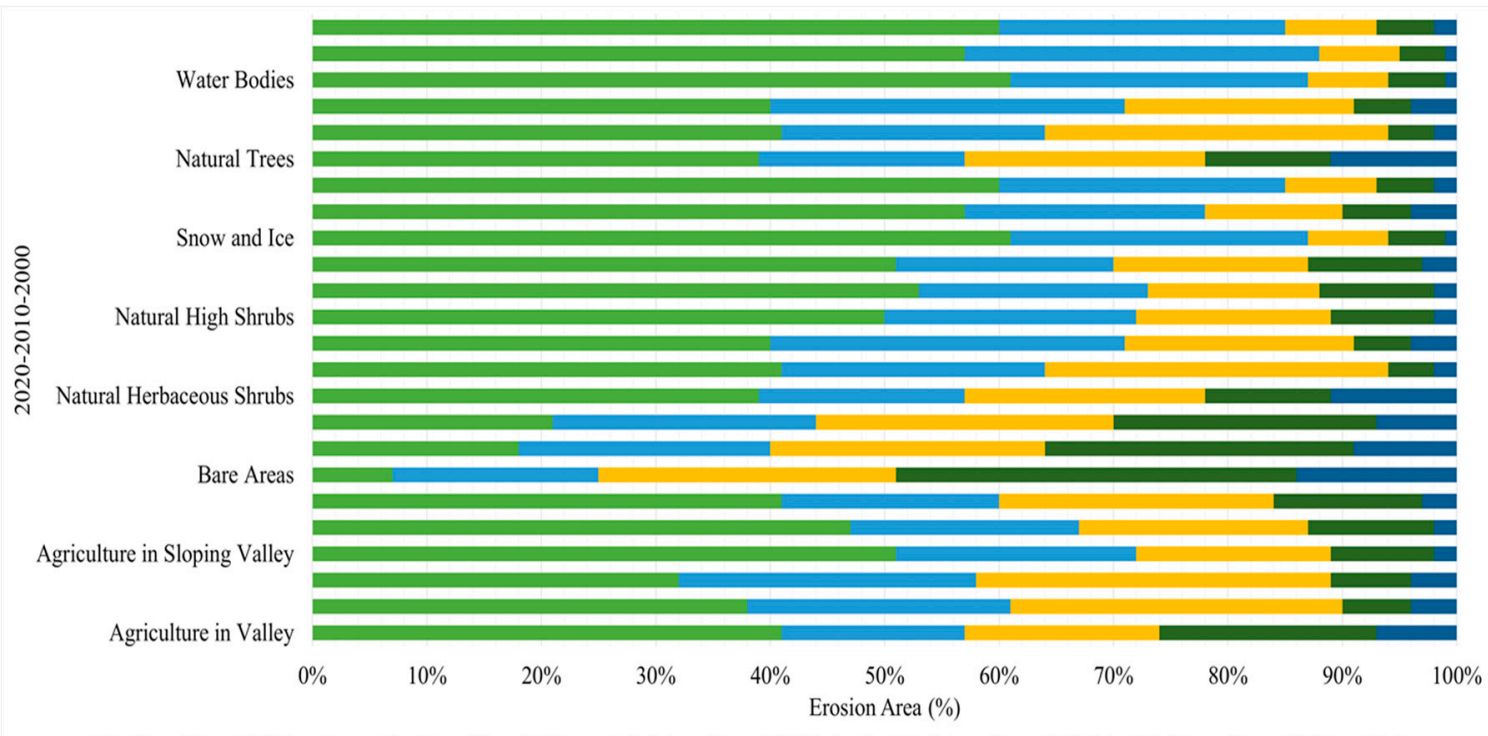

$\llbracket$ Soil loss Class (\%) Very Low $\square$ Soil loss Class (\%) Low $\llbracket$ Soil loss Class (\%) Moderate $\square$ Soil loss Class (\%) High $\square$ Soil loss Class (\%) Very High

Figure 5. Land use class-wise severity classes with a 10-year gap according to the area affected. 


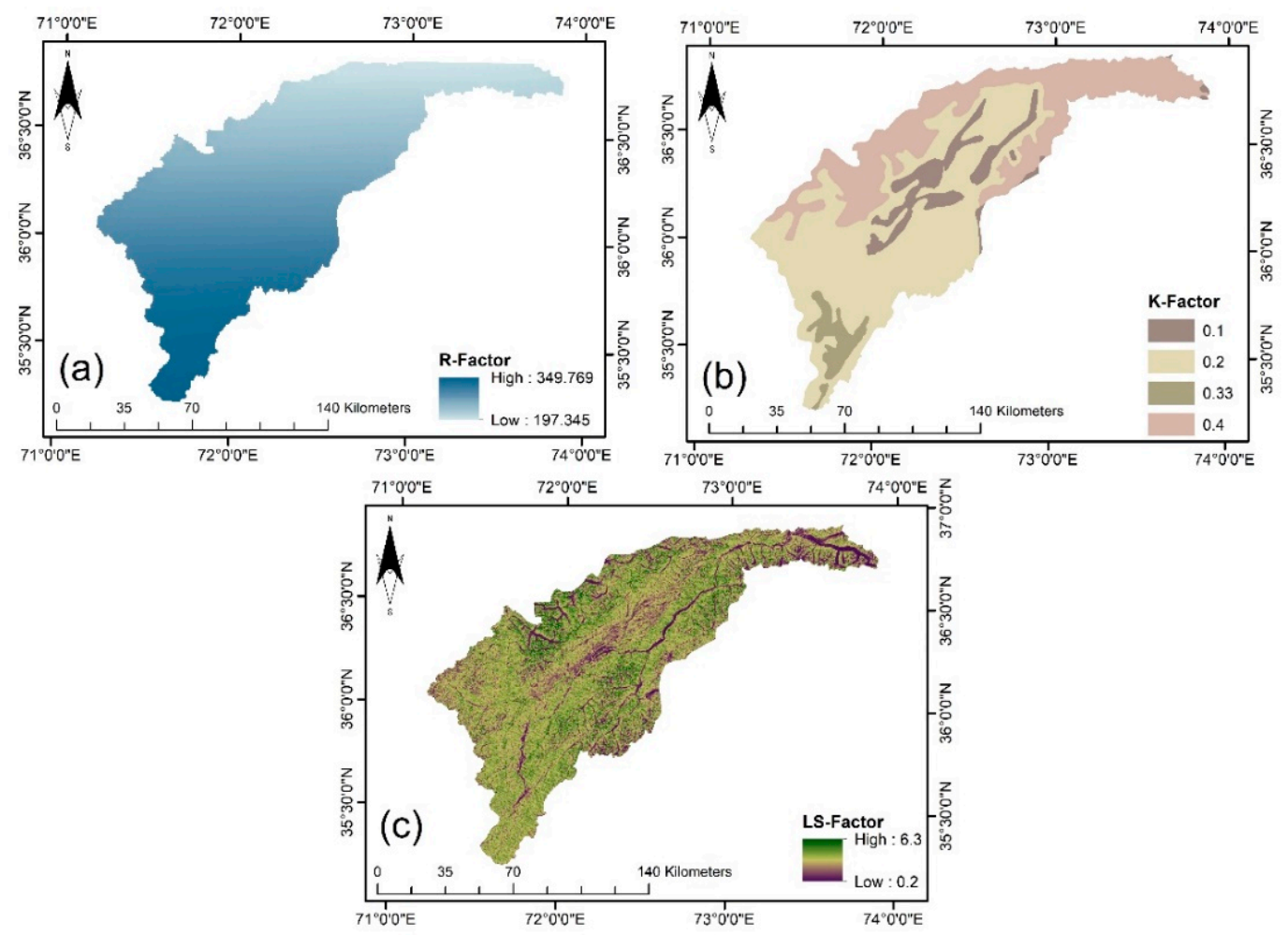

Figure 6. The RUSLE (Revised Universal Soil Loss Equation) factors for the study area (a) R factor, (b) K factor, (c) LS factor.
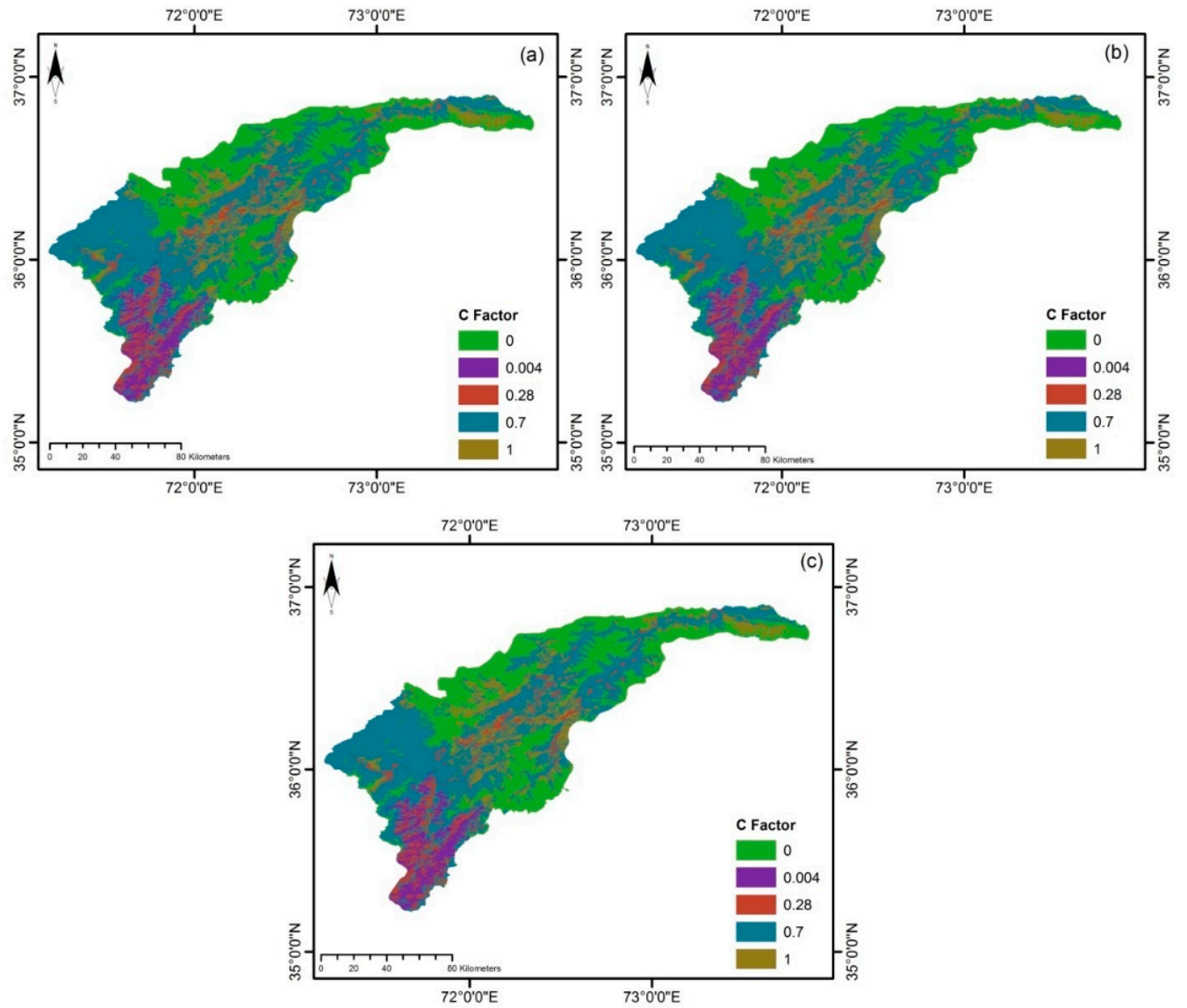

Figure 7. C factor map of the study area (a) 2020, (b) 2010, (c) 2000. 
The spatial distribution of $\mathrm{p}$ factor is not generated because there are no precautionary or conservation measures being taken against the soil erosion in this region. The values of four parameters of RUSLE out of five remain constant but the value of management ( $\mathrm{C}$ factor) shows variation both spatially and temporally. The spatial and temporal distributions of the $C$ factor are presented in Figure $7 \mathrm{a}-\mathrm{c}$. The values of the $\mathrm{C}$ factor range from 0 to 1 for all three years of study, but changes in LULC make their spatial distributions different. Sediment yield of the watershed was obtained by putting all the five parameters into the RUSLE, and the obtained results are illustrated in Figure 8a-c. The figures assist us to extract the information that the central part of the study area is predominantly affected by the sediment yield. The percentage of the affected area kept changing throughout 20 years. In the year 2000, it was $20 \%, 50 \%$ in 2010, and then changed to $80 \%$ in 2020 (Table 5). Due to anthropogenic activities, all those areas which fall in the high class in 2000 and 2010 have been transformed into a very high soil erosion hazard zone. Hence, it can be said that man-made activities further increase the potential of soil erosion in areas which are already vulnerable to soil erosion. This increased percentage of the affected area is alarming and needs to be addressed properly.

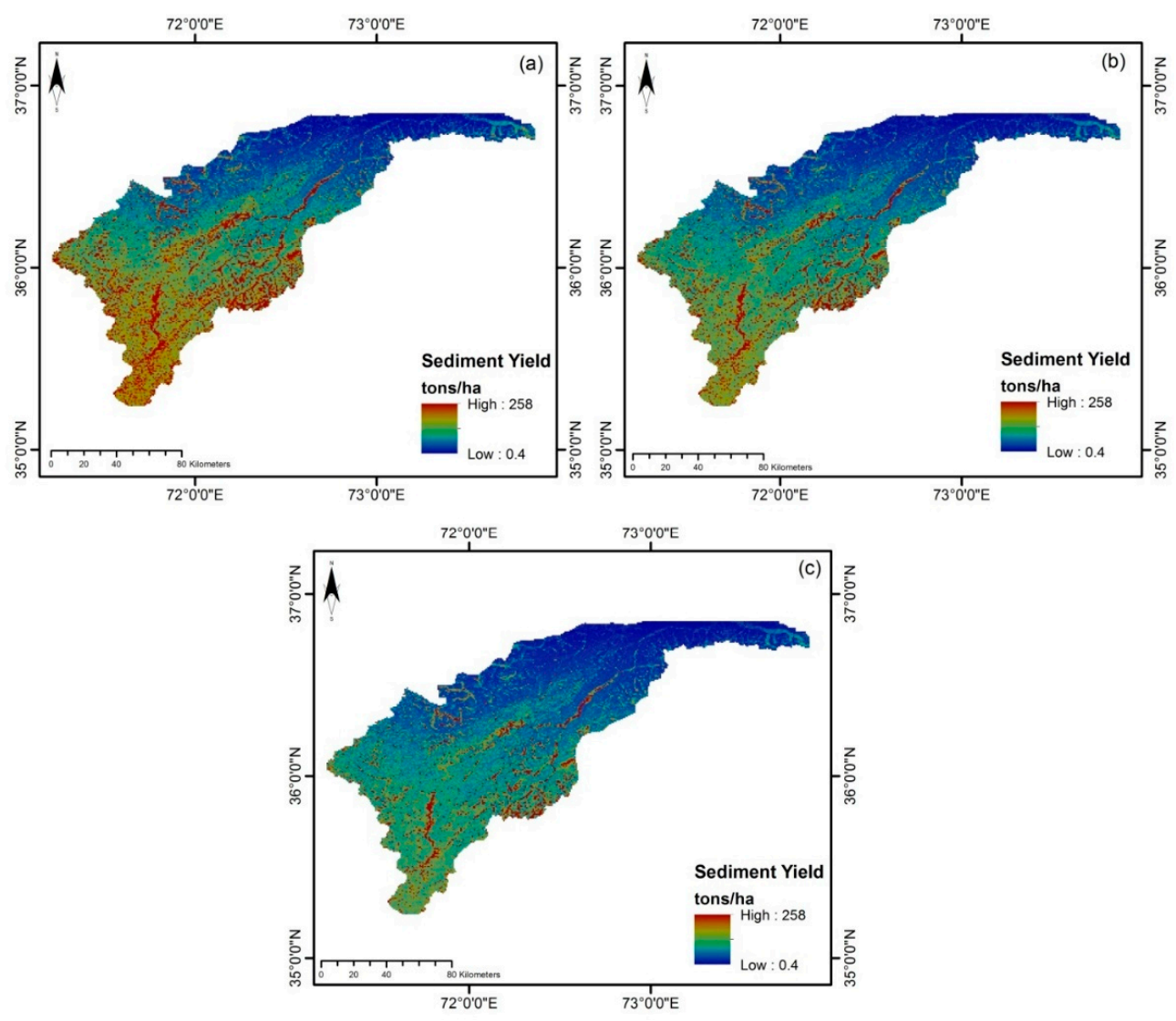

Figure 8. Sediment yield map of the study area (a) 2020, (b) 2010, (c) 2000.

Table 5. Soil erosion severity classes showing the area affected from 2000 to 2020.

\begin{tabular}{|c|c|c|c|c|c|c|c|}
\hline \multirow{2}{*}{$\begin{array}{l}\text { Soil Erosion } \\
\text { Severity Class }\end{array}$} & \multirow{2}{*}{$\begin{array}{c}\text { Soil Loss } \\
\text { (tons/ha/year) }\end{array}$} & \multicolumn{2}{|c|}{2020} & \multicolumn{2}{|c|}{2010} & \multicolumn{2}{|c|}{2000} \\
\hline & & $\begin{array}{l}\text { Total Area } \\
\text { (ha) }\end{array}$ & Area (\%) & $\begin{array}{l}\text { Total Area } \\
\text { (ha) }\end{array}$ & Area (\%) & $\begin{array}{l}\text { Total Area } \\
\text { (ha) }\end{array}$ & Area $(\%)$ \\
\hline Very Low & $<5$ & 623,122 & $43 \%$ & 536,175 & $37 \%$ & 521,684 & $36 \%$ \\
\hline Low & $5-10$ & 173,895 & $12 \%$ & 275,333 & $19 \%$ & 333,298 & $23 \%$ \\
\hline Moderate & $10-20$ & 304,315 & $21 \%$ & 362,280 & $25 \%$ & 362,280 & $25 \%$ \\
\hline High & $20-50$ & 231,859 & $16 \%$ & 202,877 & $14 \%$ & 173,895 & $12 \%$ \\
\hline Very High & $>50$ & 115,930 & $8 \%$ & 724,56 & $5 \%$ & 579,65 & $4 \%$ \\
\hline \multicolumn{2}{|c|}{ Total } & $1,449,121$ & $100 \%$ & $1,449,121$ & $100 \%$ & $1,449,121$ & $100 \%$ \\
\hline
\end{tabular}


The soil erosion of the studied watershed showed a variation on the spatial scale to some extent in all three years of this study. Singh et al. [41] suggested that the soil erosion maps of the studied years are to be classified into four soil erosion classes from a management perception such as low, medium, high, and very high. The area affected by the soil erosion was divided into five categories (Figure 9) to have a better and clear understanding. Quantification of the soil hazard is very important to identify the hazard level and hotspot regions. Usually, hazard is defined in terms of very low, low, moderate, high and very high [42]. Ranges for the soil loss tolerance level for the study area are defined by OECD [43]. Multiple researches, carried out in several parts of the region, same as study area, followed the similar soil erosion classification method [44-46]. Therefore, similar quantification technique is followed in this study while keeping ranges of this region in mind. It was categorized as very low (less than 5 tons/ha/y), low (5-10 tons/ha/y), moderate (10-20 tons/ha/y), high (20-50 tons/ha/y), and very high (more than 50 tons/ha/y). The results of the difference between the three maps are presented in Table 5. The area affected by soil erosion showed increment. It is obvious from the increment that the land cover use kept changing throughout these years. There is a net change in the total area under the very low, low, moderate, and high categories by $7 \%,-11 \%,-4 \%$, and $4 \%$, respectively. The percentage of affected areas under a very high category was $4 \%$ in the year 2000 , and it changed to 5\% in 2010 and $8 \%$ in 2020. The area under very high category is increased by $4 \%$ in the comparison between 2000 and 2020, which is a major issue of concern. The change in soil erosion and its spatial distribution is depicted in Figure 10.
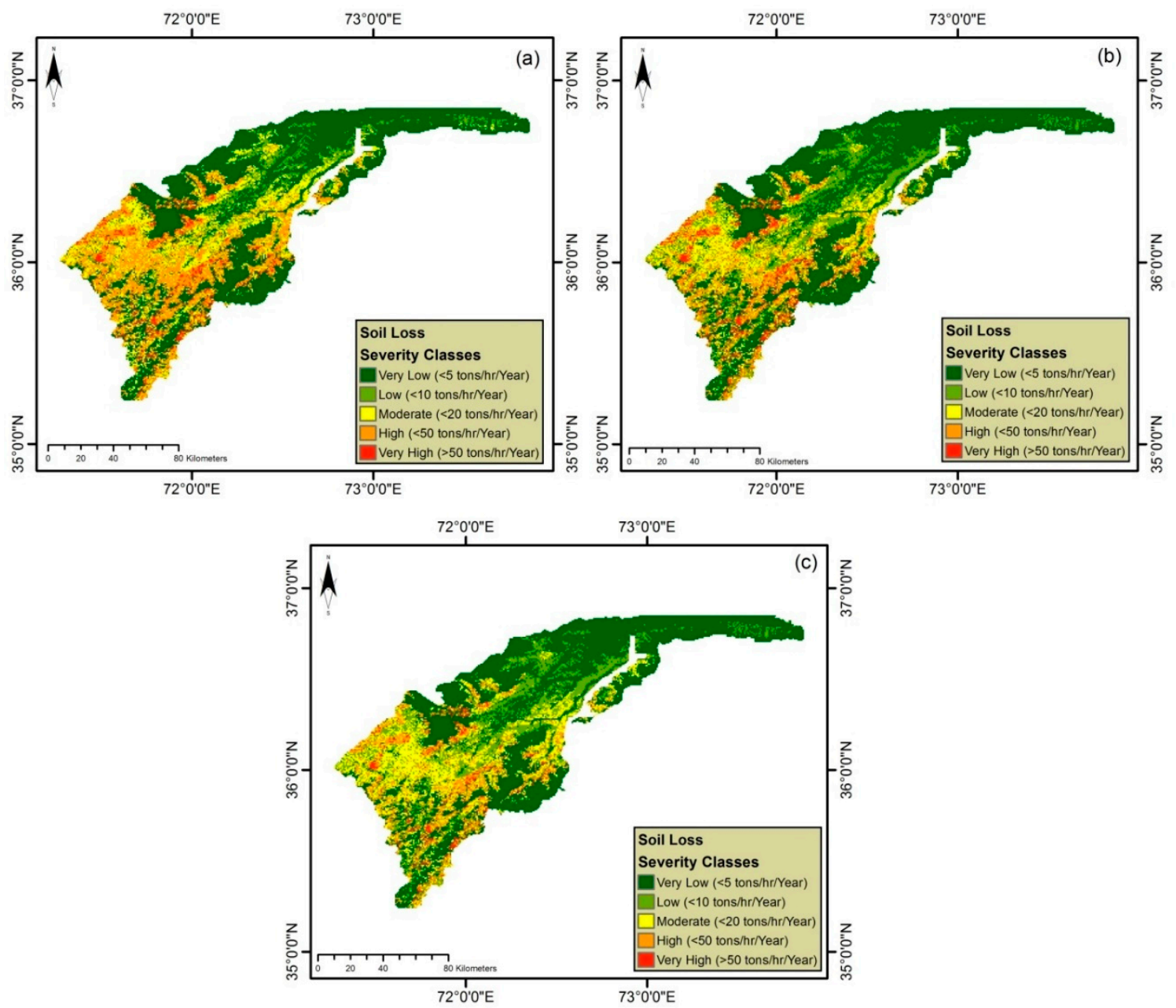

Figure 9. Soil loss severity map of the study area (a) 2020, (b) 2010, (c) 2000. 


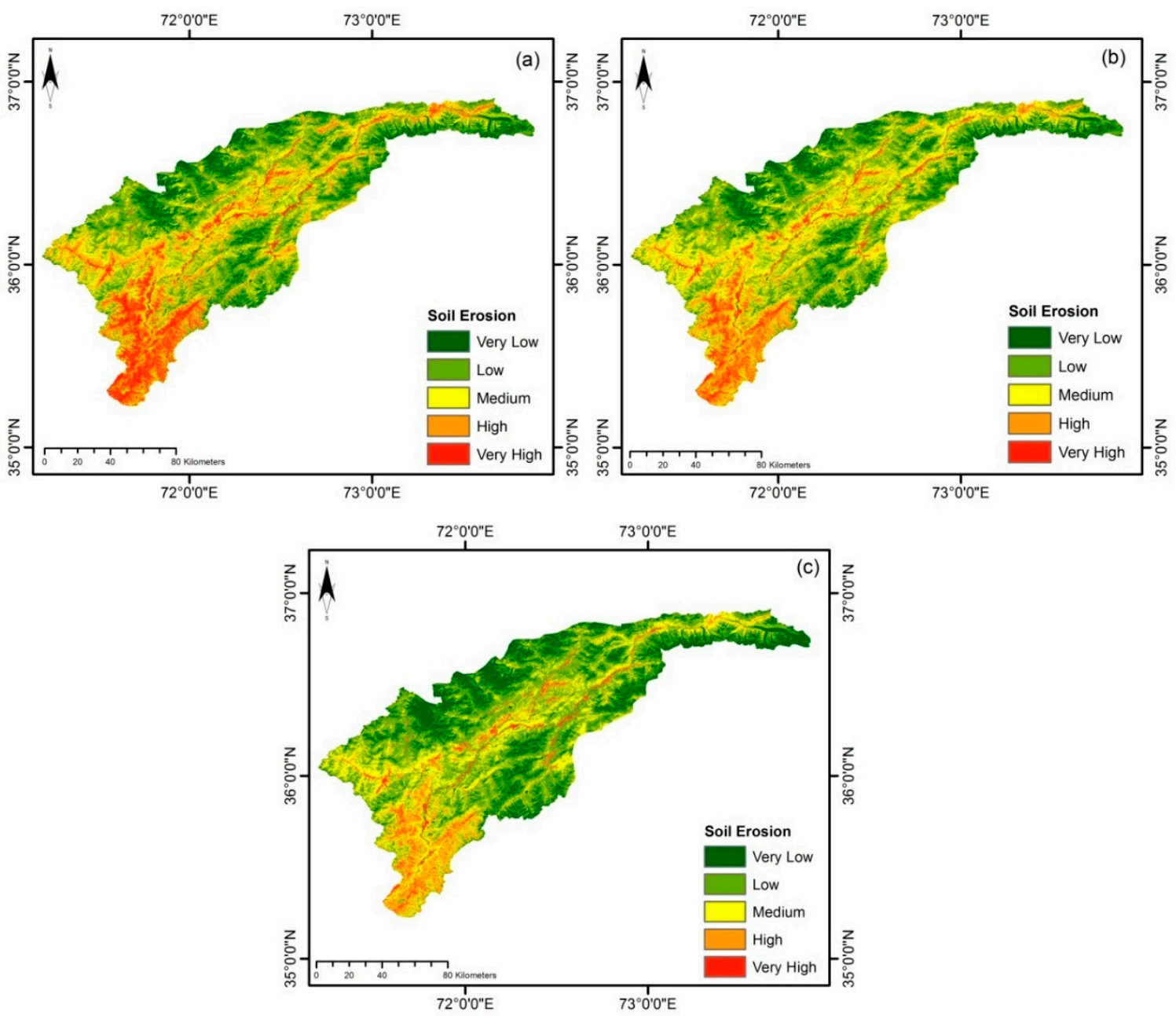

Figure 10. Soil erosion map of Chitral district (a) 2020, (b) 2010, (c) 2000.

The study area is a mountainous region. The figure shows that changes were severe in areas with high topographic potential for soil erosion during the study period. Degraded forestland, predominantly in foothill regions due to increasing human activities, is one of the main reasons behind this severe soil erosion. Invulnerable areas, land use changes in the intensification of agricultural activities and deforestation make the land more prone to soil erosion. From these results, it can be inferred that any land transition to cropland would be harmful, as it was the major source of sedimentation. On the other hand, the forest was the most effective barrier to soil loss.

With the passage of time and advancement in the knowledge of land, the cover has become essential to overcome the issues related to biogeochemical cycles, biodiversity, deterioration of environmental quality, loss of productive ecosystems, and loss of agricultural lands. The main reason behind the LULC changes includes rapid growth in population, rural-to-urban migration, reclassification of rural areas as urban areas, lack of valuation of ecological services, poverty, ignorance of biophysical limitations, and use of ecologically incompatible technologies. The present study area of Chitral is a mountainous and developing town. During the past few decades, the study area had witnessed substantial increase in population, economic growth, industrialization, and transportation activities that harmed environmental health of the region.

\section{Discussion}

The accuracy of the generated maps has improved throughout the study period. One of the main reasons is that the advancement in technology has enabled us to produce improved GIS, which can 
encounter more complex problems and issues. The results of the year 2020 are more accurate as compared to the previous years. The study conducted by [8] shows the same trend of improvement in accuracy but another study [47] shows that the accuracy for the maps in 2002 was $81.6 \%$ and it decreased to 80.5 percent for the year 2009. Thus, accuracy may depend upon one's personal skills and availability of data.

Due to the involvement of multiple data sets, we used the latest technologies like remote sensing and GIS to quantify LULC. Interpretation of remote sensing imagery, GIS and existing study area conditions enabled us to classify the study area into eight categories, that is, agriculture in sloping valley, agriculture in the valley, bare areas, natural herbaceous shrubs, natural high shrubs, natural trees, snow and ice, and water bodies. To determine the hazard potential and vulnerable hotspots, such zonation has been made in several studies. Those studies are taken as base line. Four concepts (regenerative economics, nature-based solutions, connectivity, and systems thinking) were introduced by Keesstra et al. [48] to explain the neutrality of land degradation. A study in the past includes strategies to reach UN Sustainable Development Goals more effectively [49]. Visser et al. [50] discussed the process to achieve Sustainable Development Goals (SDGs) by using transitions for soil-water system. Another study was conducted in the past to examine the geography of soil [51]. The classification of same nature has already been made in previous researches [8,47]; some other classes can also be found in the literature [52].

Table 2 shows the area covered by every land use class for the studied duration. It shows reduction in area covered by agriculture in valley, agriculture in sloping valley, bare areas, and natural high shrubs. The area occupied by natural herbaceous shrubs was reduced. The possible reason for the reduction in natural herbaceous shrubs might be the degradation of land because of nutrient depletion by intense soil erosion due to the lack of required soil conservation measures. The major class of snow and ice also shows decrement. This reduction is the consequence of global warming, the greenhouse effect, and the changing climates due to the mentioned reasons [53]. The class of bare area shows an increased percentage. It might be due to the settlement of more people in urban areas which leaves the rural areas bare [54]. Degraded forest, river sand, bare soil, heavily eroded land, and rock outcrop are included in the bare areas described in this study [8]. Natural high shrubs increased because the study area is governed by high altitude, receiving comparatively more rainfall, which excels the growth of natural high shrubs. The area covered by the water bodies is reduced due to lack of conservation practices. The agriculture in the area is increased, which is not very unusual considering the increasing demand of population and food. The highest soil erosion has a strong connection with cultivated land [8]. The strata of the cultivated soil are disturbed when it is ploughed. This disturbance of soil strata makes it more vulnerable to soil erosion. The increase in agricultural production is possible by the use of fertilizers turning uncultivable land to cultivable lands. Our study shows contrast to many other studies in which agriculture area or cultivated land is decreased due to many reasons such as conversion of agricultural land to settlements and to other land use classes such as forest [14].

Different land use types have great impact on soil erosion. The rate of soil erosion may change from area to area. It is not fixed that it will increase every time. It depends on conservation practices and management against soil erosion. Calculation of soil erosion can be divided into two categories, i.e., one for short period and the other for long period. Studies for short-term soil erosion rates are conducted in the Polish Carpathians, [35,55-60]. The Szymbark IG\&SO PAS Research Station $\left(49^{\circ} 38^{\prime} 04^{\prime \prime} \mathrm{N}, 21^{\circ} 07^{\prime} 08^{\prime \prime} \mathrm{E}\right)$, located in the Polish Carpathians, where soil erosion measurements covered the last 30 years is an exception [61-64]. A similar analysis was conducted by Latocha et al. [30] for soil erosion for a long-term period (in the last 150 years). However, their study was in the Sudetes Mountains, where after World War II, immigration actions led to depopulation and then forest expansion. This consequently decreased the soil erosion rates [14]. Our study is for the short period of 20 years and it shows that the rate of soil erosion increased from 2000 to 2020. The increment in the mean soil erosion may be due to slight transitions in land and land use. The main reason for increase in the mean soil erosion of the watershed over the studied period could be allocated to 
the drop in percentage of forest area, the increment of bare areas, and increased cultivation practice in areas that are more prone and vulnerable to soil erosion. It is important to remember that the change in the mean soil erosion may significantly affect the sedimentation process of the reservoir. LULC dynamics in the watershed result in more sedimentation in the reservoir, which would affect its life negatively. LULC dynamics obtained in this study indicate that the studied watershed is affected by moderate management and some other local human activities. RUSLE model was used to evaluate the subsequent effects of LULC dynamics on soil erosion potential.

This study shows increment in soil erosion rates. Changes in land use and land cover contributed to this increment. The LULC change was rapid in the second decade of the 21st century in the study area. It shows that the area is under many human activities such as a reduction in natural trees, snow, and ice, and increment in agriculture in plain and sloping areas as well. Increase in soil erosion can also be attributed to changes in the land cover, which are reflected by NDVI, and in turn changing the $C$ factor values which strongly affect the soil erosion. Global climate system may be altered due to LULC changes. Nearly two-thirds of the precipitation that falls on the earth's surface is returned to the atmosphere via evaporation. Precipitation amount and intensity and potential evapo-transpiration is directly affected by climate change, and it indirectly affects plant water-use efficiency through altering plant growth rate and species composition, which result in change of land cover. The figures show that the areas with high soil erosion potential were mostly located along the foothill regions in the southern part and some portions of the central watershed during studied years. This study shows contrast to many previously conducted studies such as $[14,47]$. In these studies, the rates of soil erosion decreased with changes in land use. It is obvious from all these references that soil erosion rates may change and differ for different land, land uses and land covers depending upon the topography, settlement trends and meteorology of the area. The outcomes of this study will help the stakeholders and regulatory decision makers to control deforesting, controlled agricultural farming and to take other necessary actions to minimize the rate of soil erosion. Such an efficient planning will also be helpful to reduce the sedimentation in the reservoir of hydraulic dam(s) (Warsak Dam) constructed on Chitral river, which drains through this watershed. Apart from its local implications, this study may also provide useful guidelines for the other parts of the globe having similar climate and geographical settings.

\section{Conclusions}

The study presented in this paper emphasizes on rapid assessment of LULC changes and their consequences on regional soil erosion potential in a mountainous watershed of Chitral, Pakistan. For this purpose, RUSLE model is used in combination with GIS, which is proved to be an effective tool to extract land use land cover changes. The results of the study demonstrate that LULC changes were significant during the period from 2000 to 2020. The risks of soil erosion have been increased by $4 \%$. The mean erosion potential for the whole watershed was increased from 9.2 tons/ha/y in 2000 to 15.63 tons/ha/y in 2020. A significant expansion in bare areas, agriculture in the valley, and agriculture in sloping valley has been noticed. On the other hand, there is a decrease in areas covered by water bodies and natural trees. These results indicate the significant impact of different land cover factors and human activities on LULC change, and consequently, on soil erosion.

Massive deforestation and increased agricultural land could be treated as most important reasons for increase in soil loss during the study period. This demands an immediate attention of the stakeholders, regulatory decision makers, and environmental management groups to propose comprehensive guidelines for possible LULCC. The farmers need to be provided with the capacity development programs to raise their level of awareness. An efficient system to control soil erosion will be equally helpful to reduce the sedimentation and increase the life and efficiency of hydraulic dam(s) constructed on Chitral river, which drains through this watershed. The soil loss hazard maps generated in this study could also be helpful to develop strategies to overcome food and water problems in the coming decades. 


\section{Limitations and Future Studies}

In the future, the effect of LULC changes can be estimated in other hilly and plain areas. Effects of all other influencing factors like slope, elevation, and rainfall should also be estimated by integrating RUSLE and GIS. Global climate system may be altered due to LULC changes. Nearly two-thirds of the precipitation that falls on the surface of earth is returned to the atmosphere via evaporation. The prediction about the changes in the precipitations can be made depending upon LULC changes in the study area. Additionally, LULC alters the amount of $\mathrm{CO}_{2}$ in the atmosphere. A study can be conducted to estimate the change of $\mathrm{CO}_{2}$ in the atmosphere due to LULCC. The storage capacity of the Warsak Dam is decreasing day by day due to changes in LULC which directly contributes to soil erosion. Thus, there is a need to propose some control structures in Chitral river by using BIM (building information modeling) to control soil erosion.

Author Contributions: Conceptualization, B.A. and A.M.; methodology, B.A.; software, S. and R.F.T.; validation, Z.A.K., A.M. and M.S.; formal analysis, Z.A.K.; investigation, B.A.; resources, F.A. and M.H.B.; data curation, D.F.; writing-original draft preparation, B.A. and A.M.; writing-review and editing, Z.A.K. and M.S.; visualization, S. and R.T.F.; supervision, A.M. and Z.A.K.; project administration, B.A. All authors have read and agreed to the published version of the manuscript.

Funding: This research received no external funding.

Conflicts of Interest: The authors declare no conflict of interest.

\section{References}

1. Chen, P.; Feng, Z.; Mannan, A.; Chen, S.; Ullah, T. Assessment of Soil Loss from Land Use/Land Cover Change and Disasters in the Longmen Shan Mountains, China. Appl. Ecol. Environ. Res. 2019, 17, 11233-11247. [CrossRef]

2. Hussnain, M.Q.; Waheed, A.; Wakil, K.; Pettit, C.J.; Hussain, E.; Naeem, M.A.; Anjum, G.A. Shaping up the Future Spatial Plans for Urban Areas in Pakistan. Sustainability 2020, 12, 4216. [CrossRef]

3. Stock, J.L.; Chusid, J.M. Urbanizing India's Frontier: Sriganganagar and Canal-Town Planning on the Indus Plains. Plan. Perspect. 2020, 35, 253-276. [CrossRef]

4. Maqsoom, A.; Aslam, B.; Khalil, U.; Ghorbanzadeh, O.; Ashraf, H.; Tufail, R.F.; Farooq, D.; Blaschke, T. A Gis-Based Drastic Model and an Adjusted Drastic Model (Drastica) for Groundwater Susceptibility Assessment Along the China-Pakistan Economic Corridor (Cpec) Route. ISPRS Int. J. Geo-Inf. 2020, 9, 332. [CrossRef]

5. Aslam, B.; Ismail, S.; Ali, I. A Gis-Based Drastic Model for Assessing Aquifer Susceptibility of Safdarabad Tehsil, Sheikhupura District, Punjab Province, Pakistan. Model. Earth Syst. Environ. 2020, 1-11. [CrossRef]

6. Martínez-Mena, M.; Carrillo-López, E.; Boix-Fayos, C.; Almagro, M.; García Franco, N.; Díaz-Pereira, E.; Montoya, I.; de Vente, J. Long-Term Effectiveness of Sustainable Land Management Practices to Control Runoff, Soil Erosion, and Nutrient Loss and the Role of Rainfall Intensity in Mediterranean Rainfed Agroecosystems. Catena 2020, 187, 104352. [CrossRef]

7. Chuenchum, P.; Xu, M.; Tang, W. Estimation of Soil Erosion and Sediment Yield in the Lancang-Mekong River Using the Modified Revised Universal Soil Loss Equation and GIS Techniques. Water 2020, $12,135$. [CrossRef]

8. Sharma, A.; Tiwari, K.N.; Bhadoria, P.B.S. Effect of Land Use Land Cover Change on Soil Erosion Potential in an Agricultural Watershed. Environ. Monit. Assess. 2011, 173, 789-801. [CrossRef]

9. Ouyang, W.; Wu, Y.; Hao, Z.; Zhang, Q.; Bu, Q.; Gao, X. Combined Impacts of Land Use and Soil Property Changes on Soil Erosion in a Mollisol Area under Long-Term Agricultural Development. Sci. Total Environ. 2018, 613, 798-809. [CrossRef]

10. Wiejaczka, Ł.; Olędzki, J.R.; Bucała-Hrabia, A.; Kijowska-Strugała, M. A Spatial and Temporal Analysis of Land Use Changes in Two Mountain Valleys: With and without Dam Reservoir (Polish Carpathians). Quaest. Geogr. 2017, 36, 129-137. [CrossRef]

11. Wilbanks, T.J. Socio-Economic Scenario Development for Climate Change Analysis. In CIRED Working Paper DT/WP; CIRED Working Paper DT/WP No. 2010-23; Centre International de Recherche sur l'Environnement et le Développement: Nogent-sur-Marne, France, 2010. 
12. Bucała, A.; Budek, A.; Kozak, M. The Impact of Land Use and Land Cover Changes on Soil Properties and Plant Communities in the Gorce Mountains (Western Polish Carpathians), During the Past 50 Years. Z. Geomorphol. Suppl. Issues 2015, 59, 41-74. [CrossRef]

13. Nearing, M.; Polyakov, V.O.; Nichols, M.H.; Hernandez, M.; Li, L.; Zhao, Y.; Armendariz, G. Slope-Velocity Equilibrium and Evolution of Surface Roughness on a Stony Hillslope. Hydrol. Earth Syst. Sci. Discuss. 2017, 21, 3221-3229. [CrossRef]

14. Kijowska-Strugała, M.; Bucała-Hrabia, A.; Demczuk, P. Long-Term Impact of Land Use Changes on Soil Erosion in an Agricultural Catchment (in the Western Polish Carpathians). Land Degrad. Dev. 2018, 29, 1871-1884. [CrossRef]

15. Buttafuoco, G.; Conforti, M.; Aucelli, P.P.C.; Robustelli, G.; Scarciglia, F. Assessing Spatial Uncertainty in Mapping Soil Erodibility Factor Using Geostatistical Stochastic Simulation. Environ. Earth Sci. 2012, 66, 1111-1125. [CrossRef]

16. De Moor, J.J.W.; Verstraeten, G. Alluvial and Colluvial Sediment Storage in the Geul River Catchment (the Netherlands) —Combining Field and Modelling Data to Construct a Late Holocene Sediment Budget. Geomorphology 2008, 95, 487-503. [CrossRef]

17. Adhikary, P.P.; Tiwari, S.P.; Mandal, D.; Lakaria, B.L.; Madhu, M. Geospatial Comparison of Four Models to Predict Soil Erodibility in a Semi-Arid Region of Central India. Environ. Earth Sci. 2014, 72, 5049-5062. [CrossRef]

18. Botterweg, P.; Leek, R.; Romstad, E.; Vatn, A. The Eurosem-Gridsem Modeling System for Erosion Analyses under Different Natural and Economic Conditions. Ecol. Model. 1998, 108, 115-129. [CrossRef]

19. Bayat, F.; Monfared, A.B.; Jahansooz, M.R.; Esparza, E.T.; Keshavarzi, A.; Morera, A.G.; Fernández, M.P.; Cerdà, A. Analyzing Long-Term Soil Erosion in a Ridge-Shaped Persimmon Plantation in Eastern Spain by Means of Isum Measurements. Catena 2020, 183, 104176. [CrossRef]

20. Ganasri, B.P.; Ramesh, H. Assessment of Soil Erosion by Rusle Model Using Remote Sensing and GisA Case Study of Nethravathi Basin. Geosci. Front. 2016, 7, 953-961. [CrossRef]

21. Conforti, M.; Buttafuoco, G. Assessing Space-Time Variations of Denudation Processes and Related Soil Loss from 1955 to 2016 in Southern Italy (Calabria Region). Environ. Earth Sci. 2017, 76, 457. [CrossRef]

22. Özşahin, E.; Eroğlu, İ. Soil Erosion Risk Assessment Due to Land Use/Land Cover Changes (Lulcc) in Bulgaria from 1990 to 2015. Alinteri J. Agric. Sci. 2019, 34, 1-8.

23. Guadie, M.; Molla, E.; Mekonnen, M.; Cerdà, A. Effects of Soil Bund and Stone-Faced Soil Bund on Soil Physicochemical Properties and Crop Yield under Rain-Fed Conditions of Northwest Ethiopia. Land 2020, 9, 13. [CrossRef]

24. Abdulkareem, J.H.; Pradhan, B.; Sulaiman, W.N.A.; Jamil, N.R. Prediction of Spatial Soil Loss Impacted by Long-Term Land-Use/Land-Cover Change in a Tropical Watershed. Geosci. Front. 2019, 10, 389-403. [CrossRef]

25. Chen, Z.; Wang, L.; Wei, A.; Gao, J.; Lu, Y.; Zhou, J. Land-Use Change from Arable Lands to Orchards Reduced Soil Erosion and Increased Nutrient Loss in a Small Catchment. Sci. Total Environ. 2019, 648, 1097-1104. [CrossRef] [PubMed]

26. Dissanayake, D.; Morimoto, T.; Ranagalage, M. Accessing the Soil Erosion Rate Based on Rusle Model for Sustainable Land Use Management: A Case Study of the Kotmale Watershed, Sri Lanka. Model. Earth Syst. Environ. 2019, 5, 291-306. [CrossRef]

27. Yang, Y.; Li, Z.; Li, P.; Ren, Z.; Gao, H.; Wang, T.; Xu, G.; Yu, K.; Shi, P.; Tang, S. Variations in Runoff and Sediment in Watersheds in Loess Regions with Different Geomorphologies and Their Response to Landscape Patterns. Environ. Earth Sci. 2017, 76, 517. [CrossRef]

28. Latocha, A.; Szymanowski, M.; Jeziorska, J.; Stec, M.; Roszczewska, M. Effects of Land Abandonment and Climate Change on Soil Erosion-An Example from Depopulated Agricultural Lands in the Sudetes Mts., Sw Poland. Catena 2016, 145, 128-141. [CrossRef]

29. Leh, M.; Bajwa, S.; Chaubey, I. Impact of Land Use Change on Erosion Risk: An Integrated Remote Sensing, Geographic Information System and Modeling Methodology. Land Degrad. Dev. 2013, 24, 409-421. [CrossRef]

30. Prasannakumar, V.; Vijith, H.; Abinod, S.; Geetha, N. Estimation of Soil Erosion Risk within a Small Mountainous Sub-Watershed in Kerala, India, Using Revised Universal Soil Loss Equation (Rusle) and Geo-Information Technology. Geosci. Front. 2012, 3, 209-215. [CrossRef] 
31. Efthimiou, N.; Lykoudi, E.; Karavitis, C. Soil Erosion Assessment Using the Rusle Model and Gis. Eur. Water 2014, 47, 15-30.

32. Licznar, P. Prognozowanie Erozyjności Deszczy W Polsce Na Podstawie Miesięcznych Sum Opadów. Arch. Ochr. Środowiska 2004, 30, 29-39.

33. Ullah, S.; Ali AIqbal, M.; Javid, M.; Imran, M. Geospatial Assessment of Soil Erosion Intensity and Sediment Yield: A Case Study of Potohar Region, Pakistan. Environ. Earth Sci. 2018, 77, 705. [CrossRef]

34. Samie, A.; Abbas, A.; Azeem, M.M.; Hamid, S.; Iqbal, M.A.; Hasan, S.S.; Deng, X. Examining the Impacts of Future Land Use/Land Cover Changes on Climate in Punjab Province, Pakistan: Implications for Environmental Sustainability and Economic Growth. Environ. Sci. Pollut. Res. 2020, 27, 25415-25433. [CrossRef] [PubMed]

35. Drzewiecki, W.; Wężyk, P.; Pierzchalski, M.; Szafrańska, B. Quantitative and Qualitative Assessment of Soil Erosion Risk in Małopolska (Poland), Supported by an Object-Based Analysis of High-Resolution Satellite Images. Pure Appl. Geophys. 2014, 171, 867-895. [CrossRef]

36. Maqsoom, A.; Aslam, B.; Hassan, U.; Kazmi, Z.A.; Sodangi, M.; Tufail, R.F.; Farooq, D. Geospatial Assessment of Soil Erosion Intensity and Sediment Yield Using the Revised Universal Soil Loss Equation (Rusle) Model. ISPRS Int. J. Geo-Inf. 2020, 9, 356. [CrossRef]

37. Mitasova, H.; Mitas, L.; Brown, W.M.; Johnston, D.M. Terrain Modeling and Soil Erosion Simulations for Fort Hood and Fort Polk Test Areas; Report for US Army Construction Engineering Research Laboratory, Geographic Modeling and Systems Laboratory; University of Illinois at Urbana-Champaign: Urbana, IL, USA, 1999.

38. Mancino, G.; Nolè, A.; Salvati, L.; Ferrara, A. In-between Forest Expansion and Cropland Decline: A Revised Usle Model for Soil Erosion Risk under Land-Use Change in a Mediterranean Region. Ecol. Indic. 2016, 71, 544-550. [CrossRef]

39. Vickers, N.J. Animal Communication: When I'm Calling You, Will You Answer Too? Curr. Biol. 2017, 27, 713-715. [CrossRef]

40. Panagos, P.; Borrelli, P.; Meusburger, K.; van der Zanden, E.H.; Poesen, J.; Alewell, C. Modelling the Effect of Support Practices (P-Factor) on the Reduction of Soil Erosion by Water at European Scale. Environ. Sci. Policy 2015, 51, 23-34. [CrossRef]

41. Singh, G.; Babu, R.; Narain, P.; Bhushan, L.S.; Abrol, I.P. Soil Erosion Rates in India. J. Soil Water Conserv. 1992, 47, 97-99.

42. Mahmood, A.; Oweis, T.; Ashraf, M.; Aftab, M.; Khan Aadal, N.; Ahmad, I.; Sajjad, M.R.; Majid, A. Improving Land and Water Produc Vi Es in the Dhrabi Watershed. In Assessments and Options for Improved Productivity and Sustainability of Natural Resources in Dhrabi Watershed, Pakistan; ICARDA: Aleppo, Syria, 2012; p. 27.

43. Directorate for Food, Agriculture, Fisheries Development; Policies and Environment Division. Environmental Indicators for Agriculture: Methods and Results: Executive Summary: [Agriculture and Food]; OECD: Paris, France, 2000; Volume 3.

44. Farhan, Y.; Nawaiseh, S. Spatial Assessment of Soil Erosion Risk Using Rusle and Gis Techniques. Environ. Earth Sci. 2015, 74, 4649-4669. [CrossRef]

45. Nasir, A.; Uchida, K.; Ashraf, M. Estimation of Soil Erosion by Using Rusle and Gis for Small Mountainous Watersheds in Pakistan. Pak. J. Water Resour. 2006, 10, 11-21.

46. Bashir, S.; Baig, M.A.; Ashraf, M.; Anwar, M.M.; Bhalli, M.N.; Munawar, S. Risk Assessment of Soil Erosion in Rawal Watershed Using Geoinformatics Techniques. Sci. Int. 2013, 25, 583-588.

47. Alkharabsheh, M.M.; Alexandridis, T.K.; Bilas, G.; Misopolinos, N.; Silleos, N. Impact of Land Cover Change on Soil Erosion Hazard in Northern Jordan Using Remote Sensing and Gis. Procedia Environ. Sci. 2013, 19, 912-921. [CrossRef]

48. Keesstra, S.; Mol, G.; Leeuw, J.D.; Okx, J.; Cleen, M.D.; Visser, S. Soil-Related Sustainable Development Goals: Four Concepts to Make Land Degradation Neutrality and Restoration Work. Land 2018, 7, 133. [CrossRef]

49. Keesstra, S.D.; Bouma, J.; Wallinga, J.; Tittonell, P.; Smith, P.; Cerdà, A.; Montanarella, L.; Quinton, J.N.; Pachepsky, Y.; Putten, W.H.V.D. The Significance of Soils and Soil Science towards Realization of the United Nations Sustainable Development Goals. Soil 2016, 2, 111-128. [CrossRef]

50. Visser, S.; Keesstra, S.; Maas, G.; Cleen, M.D. Soil as a Basis to Create Enabling Conditions for Transitions Towards Sustainable Land Management as a Key to Achieve the Sdgs by 2030. Sustainability 2019, 11, 6792. [CrossRef] 
51. Rodrigo-Comino, J.; Senciales, J.M.; Bolinches, A.C.; Brevik, E.C. The Multidisciplinary Origin of Soil Geography: A Review. Earth-Sci. Rev. 2018, 177, 114-123. [CrossRef]

52. Li, L.; Wang, V.; Liu, C. Effects of Land Use Changes on Soil Erosion in a Fast Developing Area. Int. J. Environ. Sci. Technol. 2014, 11, 1549-1562. [CrossRef]

53. Schneider, S.H. The Greenhouse Effect: Science and Policy. Science 1989, 243, 771-781. [CrossRef]

54. Schneider, A. Monitoring Land Cover Change in Urban and Peri-Urban Areas Using Dense Time Stacks of Landsat Satellite Data and a Data Mining Approach. Remote Sens. Environ. 2012, 124, 689-704. [CrossRef]

55. Święchowicz, J. Spłukiwanie Gleby Na Użytkowanych Rolniczo Stokach Pogórskich W Latach Hydrologicznych 2007-2008 W Łazach (Pogórze Wiśnickie). Prace i Studia Geogr. 2010, 45, 243-263.

56. Swięchowicz, J. Water Erosion on Agricultural Foothill Slopes (Carpathian Foothills, Poland). Z. Geomorphol. Suppl. Issues 2012, 56, 21-35. [CrossRef]

57. Nowak, A.; Tokarczyk, N. Evaluation of Soil Resilience to Anthropopressure in Łosie Village (Lower Beskids Mts)_Preliminary Results. Ekológia (Bratislava) 2013, 32, 138-147. [CrossRef]

58. Froehlich, W. Natezenie Erozji Gleb Na Stokach Beskidzkich W Swietle Badan Metodami Klasycznymi I Radioizotypowymi. Zeszyty Naukowe Akademii Rolniczej w Krakowie. Sesja Naukowa 1997, 48, 35-46.

59. Froehlich, W. Importance of Splash in Erosion Process within a Small Flysch Catchment Basin. Stud. Geomorphol. Carpatho-Balcanica 1980, 14, 77-112.

60. Higgitt, D.L.; Froehlich, W.; Walling, D.E. Applications and Limitations of Chernobyl Radiocaesium Measurements in a Carpathian Erosion Investigation, Poland. Land Degrad. Dev. 1992, 3, 15-26. [CrossRef]

61. Bochenek, W.; Gil, E. Zróżnicowanie Spływu Powierzchniowego I Spłukiwania Gleby Na Poletkach Doświadczalnych O Różnej Długości (Szymbark, Beskid Niski). Prace i Studia Geograficzne 2010, 45, 265-278.

62. Demczuk, P.; Gil, E. The Application of the Usle Model in the Automatic Mapping of Soil Erosion in the Bystrzanka Catchment (Flysh Carpathian). Quaest. Geogr. 2009, 28, 2.

63. Kijowska-Strugała, M. Transport Zawiesiny W Warunkach Zmieniajacej Się Antropopresji W Zlewni Bystrzanki (Karpaty Fliszowe); IGiPZ PAN: Warszawa, Poland, 2015; Volume 247.

64. Kijowska-Strugala, M.; Demczuk, V. Impact of Land Use Changes on Soil Erosion and Deposition in a Small Polish Carpathians Catchment in Last 40 Years. Carpathian J. Earth Environ. Sci. 2015, 10, 261-270.

(C) 2020 by the authors. Licensee MDPI, Basel, Switzerland. This article is an open access article distributed under the terms and conditions of the Creative Commons Attribution (CC BY) license (http://creativecommons.org/licenses/by/4.0/). 